\title{
Rūgščiojo jonizuoto vandens ịtaka sẻjamojo žirnio (Pisum sativum L.) biometriniams ir biocheminiams rodikliams
}

\author{
Regina Malinauskaitè \\ Aleksandro Stulginskio universitetas, \\ Studentu g. 11, LT-5361 \\ Akademija, Kauno r. \\ El.paštas regina.malinauskaite@asu.lt
}

Tyrimų, atliktų Aleksandro Stulginskio universiteto Biologijos ir augalų biotechnologijos instituto laboratorijoje $2015 \mathrm{~m}$., tikslas - ivertinti nuolatiniam laistymui naudoto rūgščiojo jonizuoto $(\mathrm{pH} 5,07)$ vandens poveikį sẻjamojo žirnio (Pisum sativum L.) 'Kiblukai' veislès augalų biometriniams ir biocheminiams rodikliams II ir III ontogenezès etapais, kadangi nèra aptikta duomenų apie ilgalaikio rūgščiojo vandens poveikį augalams. Kontroliniai augalai buvo laistomi vandentiekio vandeniu ( $\mathrm{pH} 7,3$ ). Rūgštusis jonizuotas vanduo buvo gaminamas iš vandentiekio vandens 0,5 val. prieš laistymą jonizatoriumi PTV-AL. Po sudygimo praejjus 7 ir 14 (II ontogenezès etapas) bei 21 ir 28 (III ontogenezès etapas) dienoms buvo nustatyti biometriniai rodikliai: augalų aukštis, antžeminès dalies žalioji ir sausoji masės, o paskutiniuoju tyrimų laikotarpiu - ir šaknų sausoji masè. Biocheminiai rodikliai: chlorofilų $a$ ir $b$ bei karotenoidų kiekis nustatyti 14,21 ir 28 dienomis.

Nustatyta, kad laistymui naudotas rūgštusis jonizuotas vanduo neturejo esminès neigiamos įtakos augalų aukščiui, bet slopino žaliosios ir sausosios masès kaupimąsi antžeminèje dalyje. Esmingai mažiau, 1,28 karto, palyginti su kontroliniais augalais, žaliosios masès buvo sukaupta III ontogenezès etape, 21 dieną po sudygimo. III ontogenezès etape ( 21 ir 28 dienomis) antžeminejje dalyje, palyginti su kontroliniais augalais, buvo sukaupta 1,26 ir 1,09 karto mažiau sausosios masès, o šaknyse - 1,11 karto mažiau. Tačiau ŠAS (šaknų-antžeminès dalies santykis) buvo panašus: kontroliniuose augaluose 0,72 , o tirtuose - 0,71. Rūgščiuoju jonizuotu vandeniu laistomuose sejamojo žirnio lapuose buvo sukaupta esmingai mažiau chlorofilų $a$ ir $b$ bei pirmaisiais tyrimų laikotarpiais - karotenoidų. Chlorofilų $a$ ir $b(\mathrm{C} a / b)$ santykis kontroliniuose augaluose svyravo nuo 2,31 iki 2,71, o tirtuose - tyrimų pradžioje 2,77, vèliau sumažèjo iki 1,61 ir 1,97. Paskutiniuoju tyrimų laikotarpiu rūgščiuoju jonizuotu vandeniu laistomų augalų lapuose pigmentų sintezè suintensyvėjo, ypač karotenoidų. Jų kiekis buvo esmingai $0,22 \mathrm{mg} \mathrm{g}^{-1}$ didesnis nei kontroliniuose augaluose.

Tyrimai parodè, kad ilgalaikis nuolatinis sejjamojo žirnio augalų laistymas rūgščiuoju jonizuotu vandeniu II-III ontogenezės etapais pradžioje slopino biomasès ir fotosintezès pigmentų sintezę, vèliau augalų jautrumas sumažèjo ir kaip atsakas ị ilgalaikị stresą prasidejjo regeneracijos procesai.

Raktažodžiai: sèjamasis žirnis, rūgštusis jonizuotas vanduo, biometriniai ir biocheminiai rodikliai

\section{IVADAS}

Augalus aplinkoje veikia daugybė stresorių. Išskirtos dvi streso formos: eustresas (teigiamai veikia augalu augimą) ir distresas (negatyviai veikia augalų augimą). Augalo atsakas ị stresą yra sudètingas procesas, nes paprastai veikia ne vienas, o stresoriu kompleksas. Todèl streso poveikis augalui yra daugialypis 
(Mittler, Blumwald, 2010). Aplinkoje stresas augalus gali veikti ilgesnị laiką, todèl jiems neužsigrūdinus (viena iš atsakomųjų i dirgiklị augalų reakcijų) gali ịvykti ir negrižžtami procesai (Shao et al., 2007). Literatūros šaltiniuose (Jaleel et al., 2009; Mittler, Blumwald, 2010) nurodoma, kad adaptacijos galimybès priklauso nuo augalo rūšies arba genotipo, veikiančių veiksnių poveikio intensyvumo, stiprumo ir veikimo trukmès.

Kaip teigia autoriai (Albert et al., 2011), augalai juos supančioje aplinkoje vienu metu yra veikiami ịvairių aplinkos veiksnių. Todèl jų fiziologinè būsena ir atsakas ị stresą gali būti îvertinti tik tada, kai augalai auginami sudètinemis streso sąlygomis.

Fiziologiniai rodikliai, kaip chlorofilo kiekis ir UV-B absorbuojančių dalelių lygis, yra informatyvūs vertinant augalų jautrumą (Juozaityte ir kt., 2006). Augimo procesas streso metu netenka būtinų metabolitinių produktų naujoms struktūroms formuotis, negauna vystymosi procesui reikalingos energijos (Chaves et al., 2009). Kiti autoriai (Juozaityte ir kt., 2006) nurodo, kad ozono streso atveju žirnių lapuose padidejo karotenoidų kiekis. Esant ilgesniam streso poveikiui, karotenoidu kiekis sumažèjo.

Vienas iš abiotinų stresorių yra vandens trūkumas, kuris riboja augalų augimą, slopina fotosintezę ir derlių (Flexas et al., 2004; Singh et al., 2011). Kiti autoriai (Sakalauskiené, 2011) nurodo, kad drègmès trūkumo sąlygomis augalams kaip gynybinė reakcija pasireiškè suintensyvejjęs fotosintezès pigmentų kaupimasis. Reakcijos intensyvumas buvo nulemtas genotipo. Literatūros šaltiniuose (Tesfaye et al., 2006) nurodoma, kad pupinių šeimos C3 augalų radiacijos sugèrimo efektyvumas esant drègmès stygiui yra jautresnis ankstyvose ju vystymosi stadijose.

Vandens pH lemia daugelị augalų cheminių, fizinių ir biologinių procesų, turi itakos maisto medžiagų, sunkiųjų metalų ísisavinimui bei pesticidų poveikiui. Dèl pakitusio $\mathrm{pH}$ gali būti inaktyvuotos veikliosios junginių medžiagos ir konvertuotos i neaktyvias. Daugeliui augalų optimalus $\mathrm{pH}$ yra 5-6,5 (Schachtman et al., 1998). Jonizacijos būdu gautas rūgštusis vanduo pasižymi baktericidinèmis savybėmis, veikia prieš patogenus ir mikroorganizmus (Kim et al., 2000), o šarminis - antioksidacinèmis savybėmis (Huang et al., 2008; Pohling, 2015). Kai kurie mokslininkai (Pohling, 2015) rūgštųji jonizuotą vandenị dèl tokio jo poveikio rekomenduoja naudoti šiltnamiuose prieš miltligę, taip sumažinti tradicinių fungicidų panaudojimą. Rekomenduojama keletą minučiu apdoroti sèklas rūgščiuoju ( $\mathrm{pH}$ 2,5-3,5) vandeniu, taip jas dezinfekuoti. Olandų mokslininkai (Hofland-Zijlstro et al., 2011) nurodo, kad rūgštusis jonizuotas vanduo gali būti plačiai panaudojamas sodininkysteje ir daržininkysteje, derinant su fungicidais ir insekticidais gèlių, daržovių ir vaisių dezinfekcijai, kovai su bakterijomis, grybais, virusais, dumbliais ir nematodais. Daugiausia jonizuoto vandens poveikio tyrimu medicinos ir maisto technologiju srityje yra vykdoma Korejoje, Kinijoje, Vokietijoje, tyrimai atliekami su šarminiu jonizuotu vandeniu (Hannes, 2012; Ignacio et al., 2012; Yoon et al., 2011). Lietuvoje pradeti tyrimai su skirtingo šarmingumo jonizuotu vandeniu siekiant išsiaiškinti jo ịtaką pupinių šeimos augalų augimui, pigmentų kiekiui lapuose, rizobijų veiklos ir gumbelių formavimosi intensyvumui. Nustatytas šarminio jonizuoto vandens poveikis pigmentų, ypač chlorofilo $a$ ir karotenoidų, kiekiams augalų lapuose bei teigiama itaka ankstyvesniam gumbelių susiformavimui ant lęšių, sojų ir kitų pupinių šeimos augalų šaknų (Malinauskaitė ir kt., 2013; Malinauskaitè, 2014).

Rūgštusis jonizuotas vanduo, pasižymintis baktericidinèmis, mikroorganizmus neutralizuojančiomis savybèmis, rekomenduojamas naudoti apsaugant augalus. Rūgščiojo jonizuoto vandens panaudojimas yra nurodomas kaip trumpalaike efektyvi priemoné augalų apsaugai (Kim et al., 2000; Hofland-Zijlstro et al., 2011). Nuolatinis tokio vandens naudojimas laistymui, ypač ankstyvaisiais vystymosi tarpsniais, gali taip pat tapti stresoriumi ir kaip augalų atsakas ị toki poveiki pasireikšti biometrinių ir biocheminių rodiklių pokyčiais. Literatūros šaltinių, kaip rūgštusis jonizuotas vanduo veikia augalų biometrinius rodiklius, fotosintezès pigmentų kieki, neaptikta.

Tyrimų tikslas - įvertinti nuolatiniam laistymui naudoto rūgščiojo jonizuoto vandens ( $\mathrm{pH} 5,07)$ poveikị sẻjamojo žirnio (Pisum sativum L.) 'Kiblukai' veislès augalų biometriniams ir biocheminiams rodikliams II (BBCH 10-19) ir III (BBCH 20-29) ontogenezès etapais. 


\section{METODAI IR SĄLYGOS}

Tyrimai atlikti Aleksandro Stulginskio universiteto Biologijos ir augalų biotechnologijos instituto laboratorijose $2015 \mathrm{~m}$. rugsejo ir spalio mènesiais. Tyrimų objektas - sejjamasis žirnis (Pisum sativum L.), 'Kiblukai' veislès augalai, $2011 \mathrm{~m}$. ši veisle įrašyta ị Nacionalinị augalų veislių sąrašą kaip saugotina.

Laboratorinis eksperimentas atliktas 4 pakartojimais. Kiekvienam pakartojimui imta po 12 sẻklų. Sèklos pasètos rugsèjo $24 \mathrm{~d}$. smèlio ir dirvožemio mišinyje (santykis 1:1). Dirvožemio $\mathrm{pH}-5,0-6,5$. Daiginimo temperatūra - $(20 \pm 22){ }^{\circ} \mathrm{C}$, auginimo temperatūra - $(16 \pm 22)^{\circ} \mathrm{C}$. Apšvietimas - natūralus. Indo talpa -2 l. Kontroliniai augalai buvo laistomi vandentiekio vandeniu ( $\mathrm{pH} 7,3)$. Rūgštusis jonizuotas vanduo ( $\mathrm{pH} 5,07)$ buvo gaminamas 0,5 val. prieš laistymą jonizatoriumi PTV-AL iš vandentiekio vandens. Pagal jonizatoriaus gamintojo rekomendacijas buvo pasirinkta jonizacijos trukmè. Po 5 min. elektrolizès vienoje jonizatoriaus talpoje buvo pasigaminęs rūgštusis vanduo ( $\mathrm{pH} \mathrm{5,07),} \mathrm{kitoje} \mathrm{talpoje} \mathrm{-} \mathrm{šarminis} \mathrm{jonizuotas}$ vanduo ( $\mathrm{pH}$ 9,66). Pirmą kartą auginimui naudojamas dirvožemis buvo prisotintas $140-150 \mathrm{ml}$ bandymo variantuose naudojamu vandeniu. Auginimo metu laistoma pagal poreiki - vidutiniškai apie $50 \mathrm{ml}$, du kartus per savaitę.

Po sudygimo 7, 14, 21 ir 28 dienomis (II ir III ontogenezès etapai) buvo tirti biometriniai ir biocheminiai (išskyrus pirmajji laikotarpị) rodikliai.

Biometrinei analizei (augalų aukštis, žalioji ir sausoji biomasès) ìvertinti buvo išmatuotas kiekvieno pakartojimo atsitiktinai pasirinktų penkių augalų aukštis $\mathrm{cm}$. Nupjovus augalą ir ji pasvèrus (kiekviename pakartojime po du augalus) svarstyklemmis KERN AJB, nustatyta žalioji augalo masè (g). Ji buvo panaudota nustatant sausąsias medžiagas (\%). Sausųjų medžiagų kiekis įvertintas džiovinant džiovinimo spintoje $105{ }^{\circ} \mathrm{C}$ temperatūroje iki nekintamos masès (LST ISO 751:2000). Paskutiniuoju tyrimų laikotarpiu nustatyta sausoji šaknų masè (\%). Tam tikslui augalai iškasti iš dirvožemio, atsargiai nuvalytas jo perteklius. Šaknys išplautos, nusausintos, pasvertos ir džiovintos tomis pačiomis sąlygomis kaip ir antžeminè dalis.

Biocheminiai rodikliai - fotosintezès pigmentai chlorofilai $a$ ir $b$ bei karotenoidai - nustatyti žalioje lapų masėje, $95 \%$ etanolio ekstrakte spektrometriniu Wettstein metodu (Gavrilenko, Zhigalova, 2003). Fotosintezès pigmentų analizei pasverta $0,2 \mathrm{~g}$ žaliosios masès, sutrinta su $0,5 \mathrm{~g}$ $\mathrm{CaCO}_{3}$, nufiltruota celiulioziniu filtru ir praskiesta etanoliu iki $50 \mathrm{ml}$. Sugerties spektrai: chlorofilo $a-662 \mathrm{~nm}$, chlorofilo $b-644 \mathrm{~nm}$ ir karotenoi$\mathrm{du}-440,5 \mathrm{~nm}$.

Pigmentų kiekis $\left(\mathrm{mg} \mathrm{g}^{-1}\right)$ apskaičiuotas pagal formulę:

$$
X=C \times V \times 100 / n \times 1000 \text {; }
$$

$C$ - pigmentų koncentracija $\mathrm{mg} \mathrm{l}^{-1} ; \mathrm{V}$ - pigmentų ištraukos tūris (ekstrakto kiekis) ml; $n$ - analizuojamojo bandinio masè.

Rezultatai pateikti kaip pakartojimų vidutinè reikšmė \pm standartiné paklaida, skaičiuojant buvo naudojamasi MS EXEL STATISTICA 7 programų paketu. Pakartojimų vidurkių esminiai skirtumai ivertinti esant $95 \%$ tikimybès lygmeniui.

\section{REZULTATAI IR JŲ APTARIMAS}

Organizmų reakcijos ì skirtingus stresorius išraiška - ịvairių biometrinių ir biocheminių rodiklių pokyčiai, pasireiškiantys kaip tiesioginis ir netiesioginis atsakas $\mathfrak{i}$ jų poveikị. Homeostazei palaikyti augalai slopina augimui skirtą kvėpavimą, eikvoja papildomą, palaikymui skirtą, energiją ir dažniausiai lètina fitomasès kaupimąsi (Madhava Rao et al., 2006). Mūsų tyrimuose nebuvo nustatytas neigiamas ilgalaikio laistymo rūgščiuoju jonizuotu vandeniu poveikis žirniams, kurie tik tyrimų pabaigoje, 28 -ą augimo dieną, buvo neesmingai, $1,50 \mathrm{~cm}$, žemesni nei kontroliniai augalai (1A pav.). Šiam tyrimų laikotarpiui nustatytas eksperimento augalų augimo tempų sumažejimas. Per tiriamąji laikotarpi kontrolinių augalų aukštis padidejo 2,0 karto, o rūgščiuoju jonizuotu vandeniu laistomų augalų - 1,9 karto.

Žirniams optimalus pH yra 6,5-7,2. Nuolatiniam augalų laistymui naudojant rūgštųji jonizuotą vandeni, kurio $\mathrm{pH} 5,07$, negatyvus poveikis (stresorius) turëjo pasireikšti per kitus biometrinius ir biocheminius rodiklius. Mūsų tyrimuose rūgštusis jonizuotas vanduo slopino žirnių žaliosios ir sausosios masès kaupimąsi (1B-2 pav.).

Vandentiekio vandeniu laistomų žirnių žalioji masè buvo neesmingai didesnè nei eksperimento augalų. Tik 21 sudygimo dieną nustatytas esmingai, 


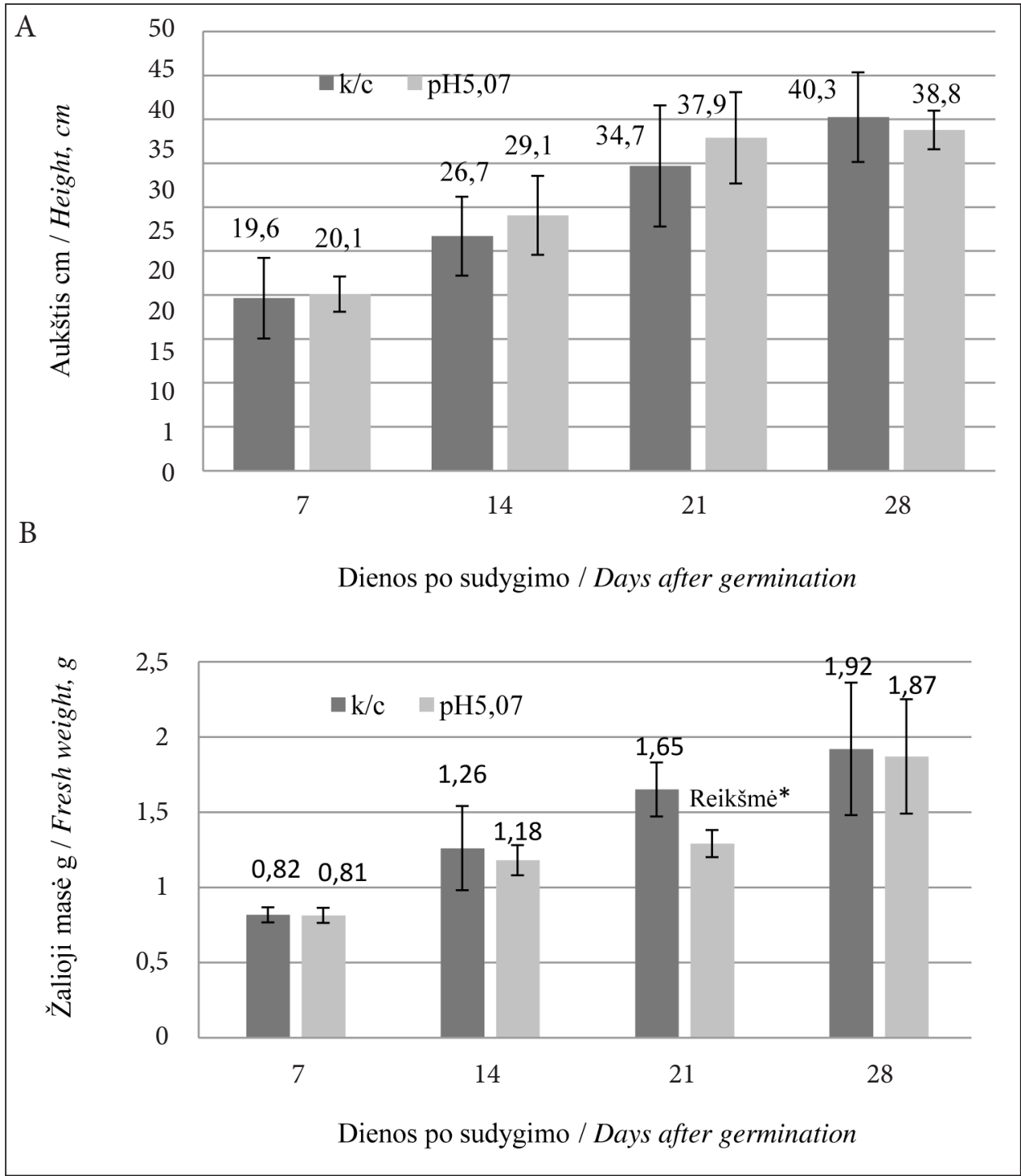

1 pav. Rūgščiojo jonizuoto vandens įtaka sẻjamojo žirnio augalų aukščio (A) ir žaliosios masès (B) dinamikai II-III ontogenezès etapais ( ${ }^{*}$ lyginant su kontroliniais augalais skirtumai yra esminiai, $P<0,05)$. Pastaba: $k$ - kontroliniai augalai

Fig. 1. Impact of acidic ionized water on the pea plant height and above-ground mass accumulation during stages II-III of ontogenesis $\left({ }^{*}\right.$ is statistically significant difference, $p<0.05)$. Note: $c$ is control

1,28 karto, didesnis kontrolinių augalų žaliosios masès kiekis. Šoninių šakelių formavimosi metu (paskutinis tyrimų laikotarpis) rūgštusis jonizuotas vanduo teigiamai veikè žaliosios biomasès prieaugi. Jis padidejo 1,44 karto, o kontrolinių augalų - 1,16 karto. İvertinus žirnių aukščio ir žaliosios biomasès pokyčius, matyti, kad rūgštusis jonizuotas vanduo turejjo ịtakos tolygesniam augalų augimui, nes buvo nustatyti mažesni standartiniai nuokrypiai, palyginti su kontroliniais augalais. Panašų poveikị (tolygesnis augimas ir fitomasès kau- pimas) turejo ir laistymui naudotas šarminis jonizuotas vanduo (Malinauskaitè, 2014).

Panašios tendencijos nustatytos tiriant sausosios masès kaupimąsi augaluose (2 pav.). Kontroliniuose augaluose, palyginti su rūgščiojo jonizuoto vandens poveikiu, esmingai daugiau buvo sukaupta sausosios masès III ontogenezès etapuose (21 ir 28 dienos po sudygimo). Paskutiniuoju tyrimų laikotarpiu dèl rūgščiojo jonizuoto vandens poveikio sausosios masès prieaugis buvo 1,48 karto didesnis nei kontroliniuose augaluose. Pirmųjų trijų tyrimo laikotarpių sukaupti mažesni sausosios masès 


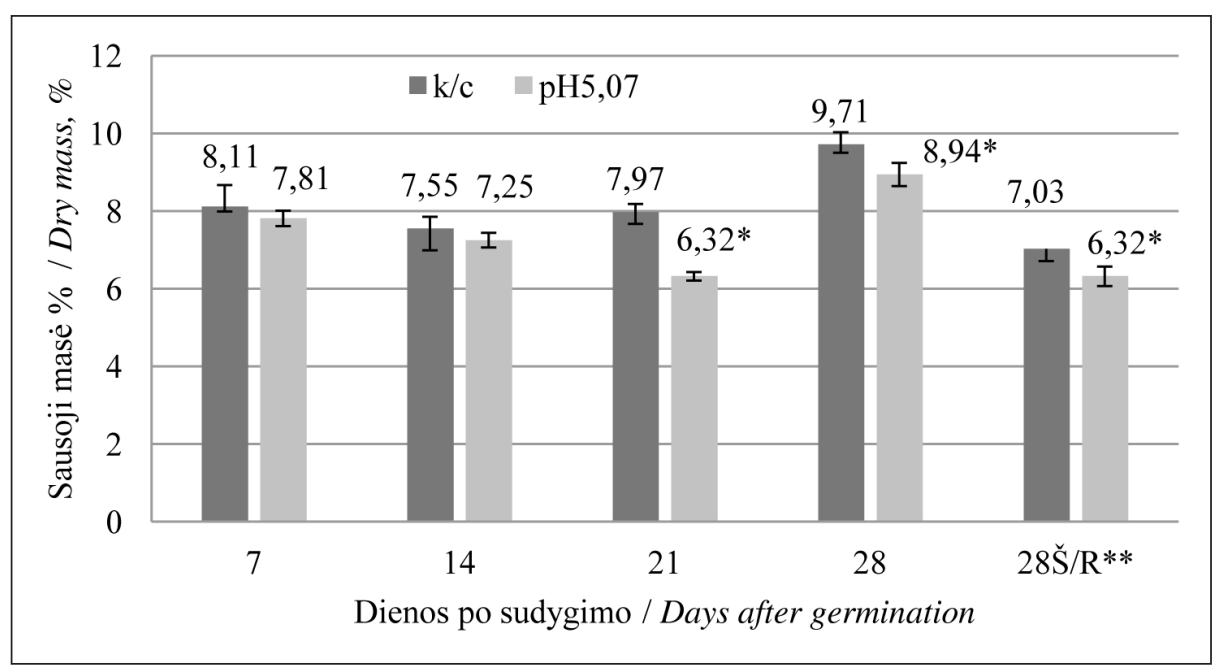

2 pav. Rūgščiojo jonizuoto vandens įtaka sëjamojo žirnio augalų sausosios masès dinamikai II-III ontogenezès etapais ( ${ }^{* \star} \check{S}$ - sausosios masès kiekis šaknyse) $\left({ }^{\star}\right.$ lyginant su kontroliniais augalais skirtumai yra esminiai, $P<0,05)$. Pastaba: $k-$ kontroliniai augalai

Fig. 2. Acidic ionized water influence on the dynamics of pea dry matter content during stages II-III of ontogenesis $\left({ }^{* *} R\right.$ is root dry matter content) $\left({ }^{*}\right.$ is statistically significant difference, $p<0.05)$. Note: $c$ is control

kiekiai dèl rūgščiojo jonizuoto vandens poveikio patvirtina literatūros šaltinių (Januškaitienè, Mikelionytė, 2009) duomenis, kad ilgalaikio stresoriaus (mažesnès UV spinduliuotės) atveju žirniuose mažèjo sausosios masès kiekis.

Ivertinus sausosios masés persiskirstymą tarp atskirų augalo dalių, galima konstatuoti, kad rūgštusis jonizuotas vanduo šiam biometriniam rodikliui neturejo neigiamos įtakos, nes šaknų ir antžeminès dalies sausosios masès santykiai kontroliniuose ir eksperimento augaluose buvo panašūs - atitinkamai 0,72 ir 0,71 . Šie rezultatai rodo nesutrikusi asimiliatų pasiskirstymą augale. Tai patvirtina ir literatūros šaltinių (Sakalauskienè ir kt., 2009) duomenys, kad pakankamas drégmès kiekis skatino sẻjamojo žirnio augalų augimo procesus, o po streso poveikio palankiomis sąlygomis greitai îvyko regeneracija.

Literatūros šaltiniuose (Shanker et al., 2005) nurodoma, kad fermentų, dalyvaujančių chlorofilo sintezèje, inaktyvinimas yra dažniausiai pagrindinè chlorofilo sintezès slopinimo priežastis. Mūsų tyrimuose dèl rūgščiojo jonizuoto vandens poveikio chlorofilų $a$ ir $b$ kiekiai visais tyrimų laikotarpiais buvo esmingai $\left(\mathrm{Ca} 0,12-0,69 \mathrm{mg} \mathrm{g}^{-1}\right.$ ir $\mathrm{C} b$ $\left.0,10-0,14 \mathrm{mg} \mathrm{g}^{-1}\right)$ mažesni nei kontroliniuose sèjamojo žirnio lapuose (3 pav.). Didesnis pagrindi- nių fotosintezès pigmentų sumažèjimas augaluose nustatytas jiems pereinant i III ontogenezès etapą. Šiuo laikotarpiu buvo nustatytas tik $0,41 \mathrm{mg} \mathrm{g}^{-1}$ chlorofilo $a$ kiekis, arba $0,40-0,46 \mathrm{mg} \mathrm{g}^{-1}$ mažiau, nei kitais tyrimų laikotarpiais. Skirtumai esminiai. Chlorofilo $b$ kiekio sumažéjimas (atitinkamai 1,19-1,56 karto) buvo esminis, bet ne toks didelis, kaip pagrindinio fotosintezès pigmento - chlorofilo $a$. Tai galima paaiškinti padidejusiu augalų jautrumo atsaku i stresorių - jonizuotą rūgštụji vandenị. Literatūros šaltiniuose (Malinauskaitè ir kt., 2013; Malinauskaitè, 2014) nurodoma, kas šarminiu jonizuotu vandeniu laistomų pupinių šeimos augalų lapuose buvo sukaupta didesni chlorofilo $a$ kiekiai. Tokie rezultatai rodo, kad šarminiam jonizuotam vandeniui būdingos antioksidacinès savybès (Huang et al., 2008) ir augalams reikia mažiau sąnaudų homeostazei palaikyti.

Kita fotosintezès pigmentu grupè - karotenoidai - yra svarbūs chlorofilų apsaugai streso sąlygomis ir veikia kaip nefermentiniai antioksidantai (Dẻdelienè, 2007). Literatūros šaltiniuose (Juozaityte ir kt., 2006) nurodoma, kad ozono streso atveju sẻjamojo žirnio lapuose padaugèjo karotenoidų. Mūsų tyrimuose tik 28 dieną po sudygimo buvo nustatytas esmingai 1,48 karto, arba $0,22 \mathrm{mg} \mathrm{g}^{-1}$, didesnis karotenoidų kiekis rūgščiuoju jonizuotu 


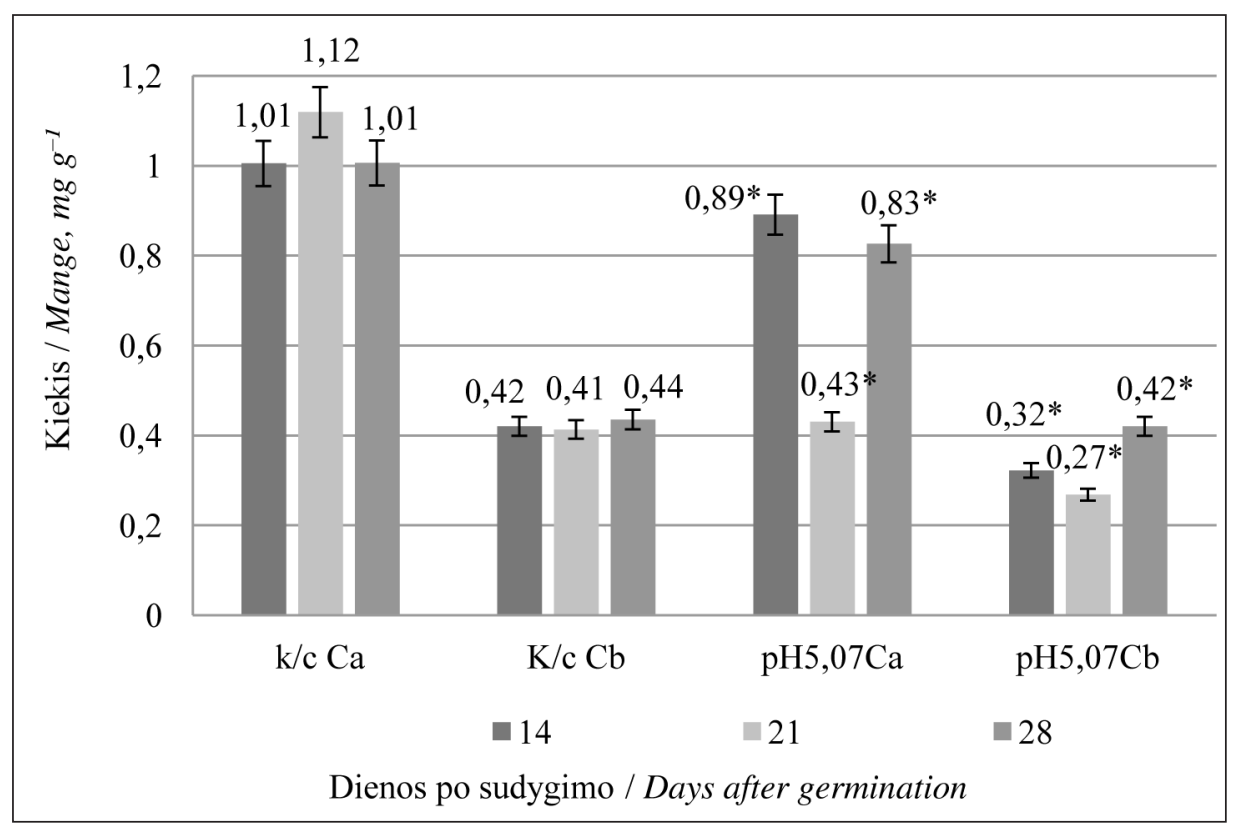

3 pav. Rūgščiojo jonizuoto vandens ịtaka sèjamojo žirnio augalų chlorofilo $a$ ir chlorofilo $b$ dinamikai II-III ontogenezès etapais $\left({ }^{*}\right.$ lyginant su kontroliniais augalais skirtumai yra esminiai, $P<0,05)$. Pastaba: $k$ - kontroliniai augalai

Fig. 3. Acidic ionized water influence on the dynamics of pea chlorophyll a and $b$ synthesis during stages II-III of ontogenesis $\left({ }^{*}\right.$ is statistically significant difference, $\left.p<0.05\right)$.

Note: $c$ is control

vandeniu laistomų sẻjamojo žirnio augalų lapuose (4 pav.). Kitais atvejais kontrolinių augalų lapuose buvo sukauptas esmingai didesnis karotenoidu kiekis.
Tokie fotosintezès pigmentų pokyčiai turèjo įtakos ir chlorofiluc $a$ ir $b$ bei juc sumos ir karotenoidų kiekio santykiams (5 pav.). Kontrolinių augalų lapuose chlorofiluc $a$ ir $b$ santykis $(\mathrm{C} a / b)$ tyrimu

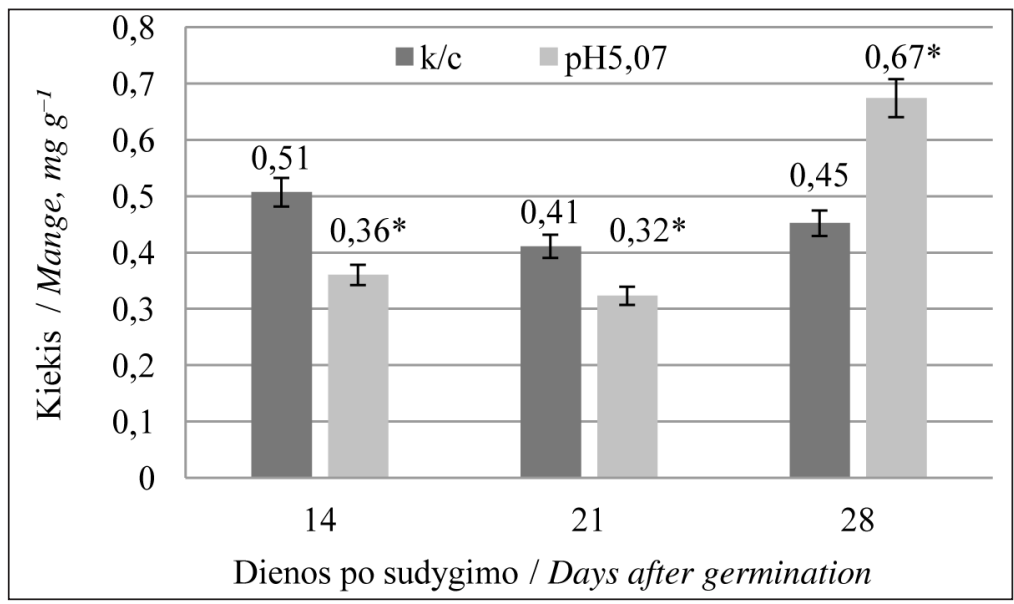

4 pav. Rūgščiojo jonizuoto vandens ịtaka sejjamojo žirnio augalų karotenoidų kiekio dinamikai II-III ontogenezès etapais (* lyginant su kontroliniais augalais skirtumai yra esminiai, $P<0,05)$. Pastaba: $k$ - kontroliniai augalai

Fig. 4. Acidic ionized water influence on the pea carotenoid content during stages II-III of ontogenesis ( ${ }^{*}$ is statistically significant difference, $p<0.05)$. Note: $c$ is control 


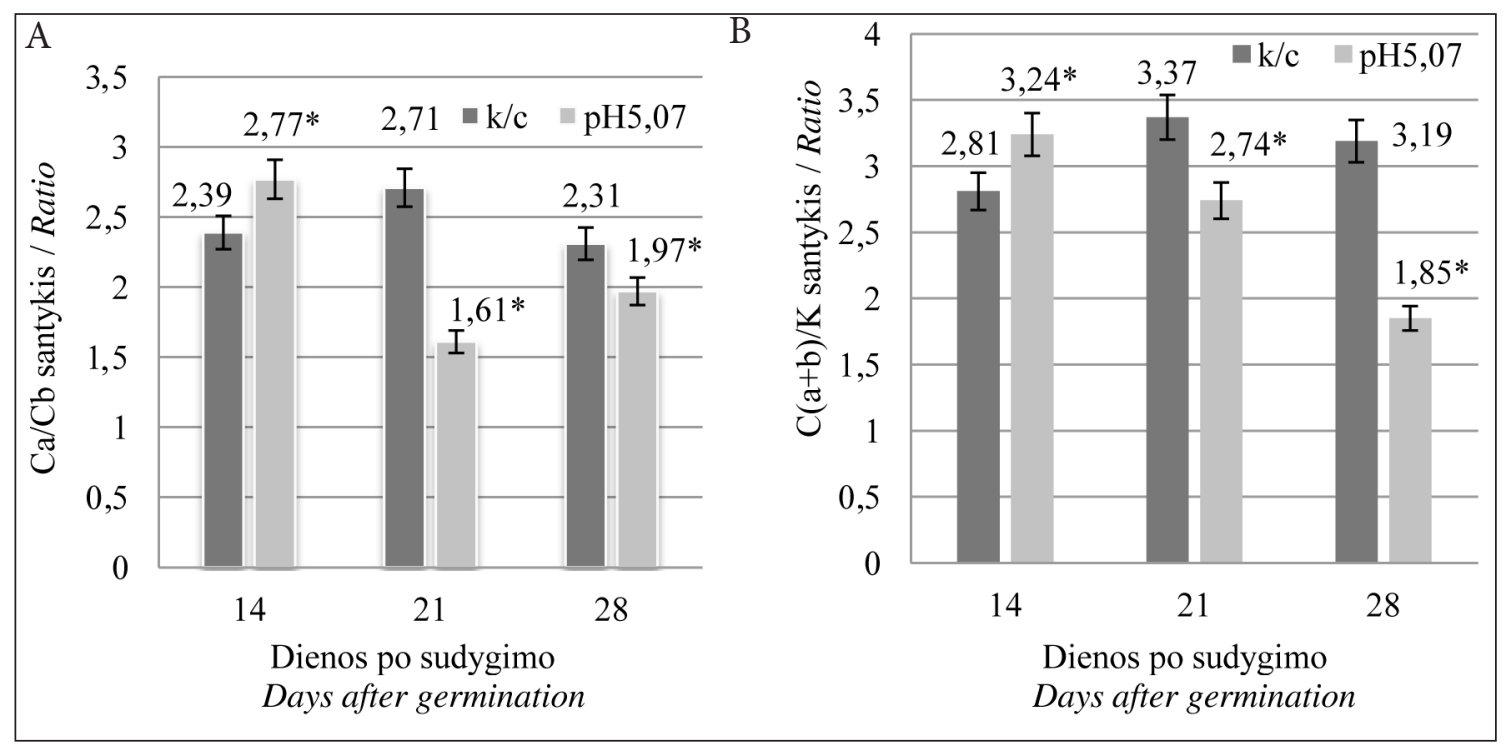

5 pav. Rūgščiojo jonizuoto vandens įtaka chlorofilų $a$ ir $b(\mathrm{Ca} / \mathrm{C} b)$ bei chlorofilų $a+b$ ir karotenoidų $(\mathrm{C}(a+b) / \mathrm{K})$ kiekio santykiams sèjamojo žirnio augalų lapuose dinamikai II-III ontogenezės etapais $\left({ }^{*}\right.$ lyginant su kontroliniais augalais skirtumai yra esminiai, $\left.P<0,05\right)$. Pastaba: $k$ - kontroliniai augalai Fig. 5. Acidic ionized water influence on the dynamics of chlorophyll $a / b(\mathrm{Ca} / \mathrm{Cb})$ and chlorophyll $(\mathrm{a}+b)$ ratio with carotenoids $(C(a+b) / K)$ in pea plant during stages II-III of ontogenesis $\left({ }^{*}\right.$ is statistically significant difference, $p<0.05)$. Note: $c$ is control

pradžioje buvo esmingai $(0,38)$ mažesnis nei eksperimentiniuose augaluose. Tačiau visais atvejais $\mathrm{Ca} / \mathrm{b}$ santykis kontrolinių augalų lapuose buvo didesnis nei 2, eksperimento augaluose III ontogenezès etape (21 ir 28 dienos po sudygimo) - mažesnis nei 2 . Toks pagrindinių fotosintezès pigmentų pasiskirstymas turèjo įtakos eksperimentinių augalų biomasès kaupimui. Tai rodo, kad ilgalaikis laistymas rūgščiuoju vandeniu veike augalo homeostazę, o jos palaikymui, kaip teigia literatūros šaltiniai (Madhava Rao et al., 2006), augalai lètino fitomasès kaupimą. Panašias tendencijas atspindi ir chlorofilų $(\mathrm{C}(a+\mathrm{b}))$ bei karotenoidų santykis. Paskutiniuoju tyrimų laikotarpiu eksperimentiniuose augaluose santykis buvo 1,85, arba esmingai 1,34 mažesnis, nei kontrolinių augalų lapuose. Šie pokyčiai susiję su žymiu karotenoidų kiekio padidejimu.

Paskutiniuoju tyrimų laikotarpiu rūgščiuoju jonizuotu vandeniu laistomuose sẻjamojo žirnio augaluose prasidejo adaptaciniai procesai, nes biometriniai ir biocheminiai rodikliai po žymaus sumažejimo, palyginti su kontroliniais augalais, pradejo didèti. Galima daryti prielaidą, kad ilgalaikis augalų laistymas rūgščiuoju, augalams nepalankiu ( $\mathrm{pH} \mathrm{5,07)} \mathrm{jonizuotu} \mathrm{vandeniu}$ ankstyvais jų vystymosi laikotarpiais slopino fi- ziologinius procesus, vėliau - augalai suaktyvino gynybines reakcijas intensyviau sintetindami karotenoidus.

\section{IŠVADOS}

1. Sejjamojo žirnio (Pisum sativum L.) 'Kiblukai' veislès augalų nuolatiniam laistymui II-III ontogenezès etapais naudojant rūgštujji $(\mathrm{pH} 5,07)$ jonizuotą vandeni buvo nustatyta, kad jis neturëjo esminès neigiamos ittakos augalų aukščiui, nes eksperimento pabaigoje jie buvo neesmingai $1,50 \mathrm{~cm}$ žemesni už kontrolinius augalus (laistoma vandentiekio vandeniu, $\mathrm{pH} 7,3$ ).

2. Rūgštusis jonizuotas vanduo slopino žaliosios ir sausosios antžeminès masès kaupimąsi. Esminiai sukauptos antžeminès masès skirtumai, palyginti su kontroliniais augalais, nustatyti 21 dieną po sudygimo (žalioji masè) ir 21 bei 28 dienomis (sausoji masè). Minètais laikotarpiais eksperimento augaluose buvo sukaupta esmingai 1,28 karto mažiau žaliosios ir 1,26 bei 1,09 karto sausosios masès. Tačiau šaknų ir antžeminès masès santykis (ŠAS) eksperimentinių ir kontrolinių augalų buvo panašus - atitinkamai 0,71 ir 0,72.

3. Sejjamojo žirnio augalų, laistytų rūgščiuoju jonizuotu vandeniu, lapuose nustatyti esmingai 
mažesni chlorofilų $a$ (atitinkamai 1,13-2,60 karto) ir $b$ (atitinkamai 1,05-1,52 karto) kiekiai.

4. Rūgštusis jonizuotas vanduo esmingai slopino karotenoidų kieki, bet tyrimų pabaigoje jų sintezè suintensyvejo - tarp paskutiniųju tyrimo laikotarpių nustatytas jų kiekio (2,09 karto) padidejjimas.

5. Nuolatinis ilgalaikis sejjamojo žirnio augalų laistymas rūgščiuoju jonizuotu vandeniu II ontogenezès etape ir pereinat $\mathfrak{i}$ III slopino fitomasès kaupimąsi, pigmentų sintezę, bet vèliau šių rodiklių, ypač karotenoidų kiekio padidèjimas, galëjo pasireikšti kaip gynybinè reakcija atstatant homeostazę.

Gauta 20160225

Priimta 20160609

\section{LITERATŪRA}

1. Albert K. R., Mikkelsen N. T., Michelsen A., RoPoulsen H., Linden L. 2011. Interactive effects of drought, elevated $\mathrm{CO}_{2}$ and warming on photosynthetic capacity and photosystem performance in temperate heath plants. Journal of Plant Physiology. No. 168. P. 1550-1561.

2. Chaves M. M., Flexas J., Pinheiro C. 2009. Photosynthesis under drought and salt stress: regulation mechanisms from whole plant to cell. Annals of Botany. No. 103. P. 551-560.

3. Dèdelienè K. 2007. Priežemio ozono ir UV-B spinduliuotés diferencijuotas kompleksinis poveikis miežiams (Hordeum vulgare L.): daktaro disertacija. Kaunas. 96 p.

4. Flexas J., Bota J., Cifre J., Escalona J. M., Galmes J., Gulias J., Lefi E., Martinez-Canellas S. F., Moreno M. T., Ribas-Carbo M., Riera D., Sampol B., Medrano H. 2004. Understanding down-regulation of photosynthesis under water stress: future prospects and searching for physiological tools for irrigation management. Annals of Applied Biology. Vol. 144. P. 273-283.

5. Gavrilenko V. F., Zhigalova T. V. 2003. Bolshoy praktikum po fotosintezu. Moskva. 256 s. (rusų kalba).

6. Hannes H. 2012. Sauere und Base im Dienst des Korpers. Aktivierter und abgereichter Wasserstoff. S. 1-36. Prieiga per internetą: http://website.gesundshop.at/literatur.pdf

7. Hofland-Zijlstro J. D., de Vries R. S. M., Bruning H. 2011. Kennisinventarisatie naar de achtergronden en toepassingen van electrochemisch geactiveerd water in de agrarische sector. P. 1-25 [žiūrèta 2016-01-19]. Prieiga per internetą: https://www. ltoglaskrachtnederland.nl/content/ltoglaskrachtnederland/docs/themas/Plantgezondheid/onderzoeksrapporten/Literatuurstudie_14347.pdf

8. Huang Y.-R., Hung Y.-C., Hsu S.-Y., Huang Y.-W., Hwang D.-F. 2008. Application of electrolyzed wa- ter in the food industry. Food Control. Vol. 19(4). P. 329. Prieiga per internetą: http://doi:10.1016/j. foodcont.2007.08.012

9. Ignacio R. M. C., Joo K.-B., Lee K.-J. 2012. Clinical effect and mechanism of alcaline reduced water. Journal of Food and Drug Analysis. Vol. 20. Suppl. 1. P. 394-397.

10. Yoon Y. S., Joo K. B., Chang B. S., Lee K. J. 2011. The effects of hot spring water on reactive oxygen species (ROS) in human study. Korea Journal Waters. Vol. 2. P. 20-24.

11. Jaleel C. A., Manivannan P., Wahid A., Farooq M., Somsundaram R., Panneerselvam R. 2009. Drought stress in plants: a review on morphological characteristics and pigments composition. International Journal of Agriculture and Biology. Vol. 11. P. 100-105.

12. Januškaitienė I., Mikelionytė J. 2009. UV-B spinduliuotès poveikis sëjamojo žirnio (Pisum sativum L.) fotosintezei ir augimui. Žemdirbyste. T. 96. Nr. 2. P. 125-137.

13. Juozaitytė R., Ramaškevičienė A., Sliesaravičius A., Burbulis N., Duchovskis P., Brazaitytè A., Samuolienè G. 2006. Sejjamojo žirnio (Pisum sativum L.) fiziologinè ir biocheminè reakcija i̇ ozono sukeltą stresą. Sodininkystè ir daržininkystè. T. 25. Nr. 2. P. 53-60.

14. Kim Ch., Hung Y.-C., Brackett R. E. 2000. Roles of oxidation-reduction potential in electrolyzed oxidizing and chemically modified water for the inactivation of food-related pathogens. Journal of Food Protection. Vol. 63. No. 1. P. 3-14.

15. Malinauskaite R. 2014. Šarminio jonizuoto vandens įtaka paprastojo lęšio 'Smèlinukai' morfofiziologiniams rodikliams. Vytauto Didžiojo universiteto Botanikos sodo raštai = scripta horti botanici universitatis Vytauti Magni. T. 18. P. 43-53.

16. Malinauskaitè R., Kazlauskas E., Šaluchaitè A. 2013. Influence of Alkaline Ionized Water on Soy bean 'DOTNUVOS RUDOJI' Growth. Rural Development 2013 : Proceedings of the 6th International Scientific Conference. Akademija. Vol. 6. B. 2. P. 164-167.

17. Mittler R., Blumwald E. 2010. Genetic engineering for modern agriculture: challenges and perspectives. Annual Review of Plant Biology. No. 61. P. 1-20 [žiūrèta 2016-01-13]. Prieiga per internetą: http:// www.bashanfoundation. org/blumwald/blumwald perspec.pdf

18. Madhava Rao K. V., Raghavendra A. S., Janardhan Reddy K. 2006. Physiology and Molecular Biology of Stress Tolerance in Plants. 345 p.

19. Pohling R. Chemische Reaktionen in der Wasseranalyse. Berlin: Springer, 2015. S. 59-65.

20. Sakalauskienè S. 2011. Kintančio klimato ir aplinkos veiksniu poveikio fiziologiniams rodikliams modeliavimas: daktaro disertacija. 88 p. [žiūrèta 2016-01-17]. Prieiga per internetą: http://vddb. 
laba.lt/fedora/get/LT-eLABa-0001:E.02 2012 D_20120130_134807-70023/DS.005.0.01.ETD/

21. Sakalauskienè S., Brazaitytė A., Šabajevienė G., Lazauskas S., Sakalauskaitė J., Urbonavičiūtė A., Samuolienè G., Duchovskis P.2009. Kompleksinis aplinkos veiksnių poveikis sẻjamojo žirnio (Pisum sativum $\mathrm{L}$.) fiziologiniams rodikliams organogenezès III-IV etapais. Žemdirbysté-Agriculture. T. 96. Nr. 3. P. 93-101.

22. Schachtman D. P., Reid R. J., Ayling S. M. 1998. Phosphorus uptake by plants: from soil to cell. Plant Physiology. Vol. 116. P. 447-453.

23. Shanker A. K., Ravichandran V., Pathmanabha G. 2005. Phytoaccumulation of cromium by some multipurpose-tree seedings. Agroforestry Systems. Vol. 60. No. 13. P. 83-87.

24. Shao H.-B., Guo Q.-J., Zhao X.-N., Su Z.-L., Hu Y.Ch., Cheng J.-F. 2007. Understanding molecular mechanism of higher plant plasticity under abiotic stress. Colloids and Surfaces B: Biointerfaces. Vol. 54. Issue 1. P. 37-45 [žiūrèta 2016-01-13]. Prieiga per internetą: http://www.sciencedirect. com/science/article/pii/S0927776506002104

25. Singh K. S., Reddy R. K. 2011. Regulation of photosynthesis, fluorescence, stomatal conductance and water-use efficiency of cowpea (Vigna unguiculata L. Walp.) under drought. Journal of Photochemistry and Photobiology B: Biology. Vol. 105. P. 40-50.

26. Tesfaye K., Walker S., Tsubo M. 2006. Radiation interception and radiation use efficiency of three grain legumes under water deficit conditions in a semi arid environment. European Journal of Agronomy. No. 25. P. 60-70.

\section{Regina Malinauskaitè}

\section{IMPACT OF ACIDIC IONIZED WATER ON PEA} BIOMETRIC AND BIOCHEMICAL PARAMETERS

Sum mary

The aim of research was to investigate the impact of $\mathrm{pH} 5.07$ acidic ionized water on the biometric and biochemical parameters of pea (Pisum sativum L.) 'Kiblukai' during stages II and III of ontogenesis. The control variant was watered with tap water.

The results indicated that the acidic ionized water did not show a significant impact on the plant height, but at the same had an inhibitory effect on the accumulation of dry matter in the above-ground part and roots of pea. During the 21st day after germination (stage III of ontogenesis) the acidic water application resulted in the significantly reduced biomass accumulation, by 1.28 times, compared to that of the control variant. During the 21st and 28th days of measurement the above-ground dry matter content in the experimental variant was reduced by 1.26 and 1.09 times, respectively, whereas the root dry mass was lower by 1.11 times, compared to that of the control. In both variants the ratio between the root and above-ground biomass was almost the same - 0.7. The biochemical analysis revealed that the acidic ionized water significantly reduced the synthesis of chlorophyll $a$ and $b$, whereas the synthesis of carotenoids was inhibited only at the first stage of the experiment. The chlorophyll $a / b$ ratio in control plants varied from 2.31 to 2.71 , while after the treatment of acidic water the ratio was 2.77 at the beginning of the experiment and later decreased to 1.61 and 1.97. The long-term effect of acidic ionized water was seen as an increasing synthesis of carotenoids, when the concentration at the last stage of the experiment significantly increased to $0.22 \mathrm{mg} \mathrm{g}^{-1}$.

Keywords: pea, acidic ionized water, biometric and biochemical parameters 